\title{
Performing Identities and Convergent Aesthetics in Contemporary Estonian Video Art
}

\author{
Inga Untiks
}

As the international contemporary art world becomes increasingly globalized, artists have recurrently reflected upon the growing connectivity amongst creative producers and their audiences that has materialized due to the possibilities of travel, communications technology, and the shared reception of words and images. The work by an emergent young art scene in the Estonian capital of Tallinn in the early 1990s began to address this transformation by adapting and integrating discourses recognizable to the international contemporary art world. These discourses present thoughtful reflections on the mobility of artists, the circulation of cultural content, and the locations of contact in the transnational traffic of art. However, the emergence of a perceptible convergence in terms of form, style, and content by Estonian artists is indicative of a more precise convergence of institutionalized art processes that produced a particular brand of standardized, internationally recognizable works. An examination of performance-based video works by Kai Kaljo and Jaan Toomik provides insight into the context of the emergence and the conditions of the use of performance-based video art in Estonia that is indicative of a shift in the cultural logic and implies the role of the audience as being critical to artistic production and interpretation.

The perceptible uniformity of artistic practice that emerged from the former Soviet republics of Estonia, Latvia, and Lithuania in the Baltic Sea region in the 1990s may be read as a symptom of the new realities of cultural capitalism in a globalized world. Insight into the applicability of media such as video art as a productive approach by contemporary Estonian video artists to address changed no- 
tions of spectatorship may be gained by extending Henry Jenkins's notion of 'convergence' as outlined in Convergence Culture: Where Old and New Media Collide (2006). Jenkins's broad definitions of 'media convergence' and 'participatory culture' are particularly salient when extended to considering the search for personal and collective connectivity by artists and audiences that have been shaped by the mobility of the contemporary art world. As artists and audiences increasingly participate in shared discourses, extensive aesthetic and contextual commonalities become apparent. Yet works resulting from these discourses also reveal the limitations of their applicability to artistic works and reflect broader systematic commonalities and prevailing directives of artistic production and dissemination in the international contemporary art world. When considered in the context of the exhibition structures of the contemporary art world and its institutionalized modes of spectatorship, the video works of both Kaljo's $A$ Loser (1997) and Toomik's Way to Sao Paulo (1994) provide evidence of a converged aesthetic preference that has affected the ways in which contemporary art is internationally produced and experienced.

While invariably being part of broader processes of personal and collective self-definition in the post-socialist era, for Estonian and indeed most Baltic artists the socio-political changes of the late 1980s and early 1990s were most rapidly and distinctly experienced with regard to the administration and financing of art, which had a far more significant impact on aesthetic developments than commonly acknowledged. ${ }^{1}$ Artists such as Kai Kaljo (b. 1959) and Jaan Toomik (b. 1961), born during socialism yet maturing during the early capitalist period of the 1990s, have distinguished themselves from the previous generation of 'unofficial' or 'nonconformist' artists who often espoused a critical distance between their art works and the socio-cultural realm in which they were produced. Instead, they are explicit about the influence of their social, political, and economic circumstances and have accordingly fashioned distinct identities.

The initial interest in the post-socialist art of the 1990s by the contemporary art world and the international art market often depended upon 'Western' assumptions of 'East European-ness,' and to artists from Eastern Europe it quickly became apparent that a particular brand of expression and experience was of interest to international curators and collectors. Undoubtedly the impulse towards 'Westernism' was strong amongst many of this generation of Estonian artists who were influenced by their personal and collective circumstances. Yet the predictable attraction to the 'exotic' or 'otherness' by the Western-based international art world in the 1990s was often framed in international exhibitions either along national boundaries or thematically according to Cold War divisions.

For artists ambitious to participate in the international exhibition network, the interest of the global art world was often in equal parts flattering and frustrating

1 While most considerations of Estonian contemporary art of the 1990s acknowledge the administrative and financial challenges faced by artists and the necessity of finding new modes of support, few directly address the aesthetic implications of changed patronage structures (see Helme 2001). 
and it was based on limited assumptions, experiences, and particular discourses. Estonian artists themselves were undeniably aware of internationally situated (or more specifically Western) readings of their performative video works and understood that the use of video technology was a central strategy to participate in international contemporary art discourses despite the lack of a regional historical legacy of the medium. While video art today still remains one of the most prominent communication devices for contemporary artists, the form was a particularly effective approach when combined with the accessibility of television in the late 1980s and early 1990s. The struggle for Estonian, Latvian, and Lithuanian independence from the Soviet Union during the Singing Revolution era of 1987-1991 in the Baltics was captured by television cameras that transmitted powerful images of cultural unity not only across the region but also to the rest of the world. Thus television and video images were made relevant to the general public for the first time, projecting the excitement and uncertainty of social and political change in the making in real-time. ${ }^{2}$ As some of the first 'honest' portrayals of the circumstances, such video footage for the local audience was not only of historical value but also significant for its reflective potential.

Although, in the early period of change, many in the region remained skeptical of the accuracy of the filmed material projected by state television networks, the direct impact of the frank images cannot be denied. As Baltic artists began to explore these potentially critical images in their performative video works, the development of new personal and collective identities during the process of mental and physical re-territorialization held a significant claim on the imaginations of both the artists and their publics. The choice of performance-based video as a medium by artists from the former Soviet republics is perhaps surprising since experience with the medium as applied to international art discourses in Estonia was largely limited. News of international art developments during the Soviet period had reached the Baltics only via print media, and a critical lack of the audience's direct sensory experience of art works (in any medium but particularly in the form of video) allowed for little insight into the context of their creation. As the historical trajectory of video works as understood in the West morphed into a more transcultural view of traditional concepts of art history, the ramifications of their use by Estonian artists had very different social and political implications.

Whereas the use of the medium of video by Estonian artists only emerged in the late 1980s as an effective means of artistic communication, body-based performative practice may be identified as a continuous phenomenon in the region

2 Latvian film and documentary director Juris Podnieks famously captured the tensions of Baltic independence during an attempted coup by Soviet forces in Riga in January 1991. While filming the clashes, Podnieks was wounded as were two of his crew members (Andris Slapins and Gvido Zvaigzne) who later died of their injuries. Footage from this conflict was subsequently included in a version of his film Homeland that focused on the rise of national identity in Latvia, Lithuania, and Estonia. 
since the 1960s. While video art in other countries during the 1970s was rapidly developing, in Estonia (and the rest of the Baltics) the focus of avant-garde artistic production outside official socialist institutions remained on liberating painting from the influences of a post-impressionist school linked to Pallas, which was achieved with the help of hyperrealism. ${ }^{3}$ However, Juri Oka's happenings and landart objects in the early 1970s were captured on $8 \mathrm{~mm}$ film and their recording, while secondary, was not unimportant for its potential to document the events and share them with other artists. This trend of using film and video for their documentary potential continued throughout the early 1980s and was of particular importance for happenings at the University of Tartu organized by various collectives whose recorded performances began to cross international borders with the loosening of socialist restrictions in the mid- to late-1980s (see also Helme 2002).

By the 1990s, performative works in their various manifestations dispersed into several different directions and subcultures, losing the common platform of 'unofficial' or 'non-conformist' opposition that had made performance art of previous decades a critical medium. However, this disintegration into interdisciplinary experimentation also expanded the potential of performance by the inclusion of video and other digital technologies for which the region has become internationally acknowledged. ${ }^{4}$ Once linked with video technology, performance-based practice quickly developed beyond early experiments in mere documentation to include video as a conceptual extension of the artistic action itself. The ambiguous gestural narratives and oblique significations of performance that had developed as alternative modes of communication during the socialist era continued to undermine representative economies when applied to video art commenting on the contemporary condition. Here, the loss of stability and identity resulting from the sociopolitical changes of the 1990s was expressed and analyzed by artists in the most basic terms of the human body and then documented on video, thus encouraging Estonian artists to examine their own reflections objectively on screen.

While national museums remain legitimizing forces for unstable national cultures such as the former Soviet republics in the annals of art history, habitual lack of local support for contemporary or avant-garde works required that art and cultural institutions as well as artists be adaptive in the age of global capitalism. The translation of these performative aspects into formats and technologies often at odds with specific 'national' traditions (i.e. the lack of the artistic self) corroborated

3 The Art School of the Pallas Arts Association was founded in 1919 in Tartu where a number of avant-garde artistic styles converged. Taking the avant-garde artistic developments occurring in Paris as a source of inspiration, the work of Pallas School members focussed on individuality, spirituality, and treatments of light and colour.

4 Estonia is acknowledged as having one of the highest internet penetration rates. Internet connections in the country were introduced in 1992 by the universities in Tallinn and Tartu, and subsequently widespread wireless broadband access was developed on new mobile data networks. Due to its geographical location, Estonia also played an important role in mediating internet culture to neighbouring Russia. 
the current belief in "otherness and diversity" (Groys 2013, 157) as interpreted by the elite international art world. The end of consistent financing by the Ministry of Culture as well as Artists Unions following the collapse of the Soviet Union left a significant void in the production and exhibition of art at an institutional level, and the lack of an established system of independent private galleries further complicated the situation. ${ }^{5}$ The resulting dependence on support by private foundations, most notably by the infamous Soros Centers for Contemporary Art (SCCA), received much criticism that warrants inquiry into the policies of fund allocation which explicitly favoured video art.

The Estonian branch of the foundation, the Soros Center for Contemporary Art-Tallinn, was opened in 1992 as part of the network of Central and East European Open Society Foundations financed by the renowned philanthropist George Soros. The failure of state museums to acclimate both organizationally and financially during the first period of transition away from state-organized infrastructures to the market-oriented system resulted in a disruption in arts administration that the Soros Foundation attempted to address (Helme 2001, 37). Yet the intricacies of the foundation's policies resulted in a shift that molded the future practice and policy until funding was pulled from the region in the late 1990s.

Initially, Soros emphasized the development of an economic, legal, and media reform in the Baltic countries; however, special recognition was also given to the processes of art and culture. The plans and ideology of the SCCA organizations were clear and uniform, with similar patterns of funding throughout all national chapters, and this strategy proved highly successful in aiding local arts professionals in becoming acquainted with Western artistic practice. The central purpose of the centres was to make it possible for locals to relate to the international art scene through initiatives such as exhibitions, symposia, and archives that were made accessible on multiple media platforms. Yet what qualified as contemporary art was largely limited to particular aesthetic strategies including video art. Furthermore, and importantly, the work of the SCCA was directed towards awarding grants that financially assisted artists, arts professionals, and projects concerned with new technologies and their application in the arts - a highly significant objective that resulted in a very strong bias towards video art, which infused the medium with democratic and capitalistic values and attributes that we are familiar with in the West and that are therefore of interest to the international art world and its markets. Logistically, according to the Open Foundation mandate, all activities were to be based on a firmly constructed plan separated into three divisions, which in turn also contained several subdivisions: grants for supporting new media artists, the documentation of contemporary art, and assistance with the development of and participation in national and international exhibitions. In practice, it was a highly

5 These circumstances presented further challenges to those working in the traditional visual arts of painting and sculpture that maintain a strong tradition in the region yet received little interest or support in the early post-Soviet period. 
specific mandate that set the foundation for the development of a particular brand of video art.

As a result of this funding structure, annual exhibitions at the SCCA-Tallinn from 1993 to 1997 were strategically limited to introducing new media art to and supporting video art production and theory in the Estonian contemporary art world. Participation in these exhibitions was open to competition and they were curated by the SCCA complete with published catalogues in both English and Estonian, which allowed for the exposure of Estonian art to an international public. While the exhibitions reflected the goals and the ideology of the SCCA, board members consisting mainly of local arts professionals based in Tallinn and interested in Western contemporary art trends took into consideration discourses developing internationally, which in practice placed additional pressure on artists to produce works within the preferred media (Helme 2001, 38).

The presentation of young artists through SCCA-Tallinn exhibitions and catalogues was significant, and there is a direct correlation between participation in Soros-funded activities and the success of a number of Estonian artists in the international mainstream. It may be argued that the predetermined preference for new media technology was simply a matter of encouragement for young artists to produce work that would engage in the convergent discourses of the international contemporary art world. However, the adaptation, appropriation, and/or translation of Western art discourses often differed significantly from the local tradition of art. Hence a significant separation developed between the aesthetic intentions of artists who had followed the Estonian trajectory of traditional art forms and those who desired to participate in global art discourses, thus further subdividing the Estonian art world into disparate groups.

While many museums began to internalize corporate models of activity in the 1990s, biennials and temporary international exhibitions became critical sites of experimentation and vital alternatives to museums and other institutions for Estonian artists who attempted to develop their own style to address specific tensions, conflicts, fears, and expectations. The international biennial exhibition format has become a significant mediator in artistic production and consumption in recent years, and its evolution has had specific implications for artists from the non-Slavic former Soviet republics of Estonia, Latvia, Lithuania, and East Germany. As spectacular arenas where the national and international frequently intersect, biennials attract significant exposure. They create an important interface between artists and their publics in contexts such as the Baltic Sea region where there are few permanent prestigious institutions and they offer a challenge to the hegemony of museums over art history. Yet, as biennials have proliferated across the globe, the expansion of the biennial system has given rise to a network of institutions and curators who seek cultural identity in regional art in order to gain global recognition. 
"Hi, my name is Kai Kaljo. I am an Estonian artist. My weight is $92 \mathrm{~kg}$.

I am 37 years of age but still living with my mother. I am working at the Estonian Academy of Art as a teacher for $\$ 80$ a month. I think the most important thing about being an artist is freedom. I am very happy." (Kai Kaljo, A Loser, 1997)

The video artist Kai Kaljo is one of the internationally best-known examples of Estonian performative video work, mainly because of her honest portrayal of the failed post-Soviet condition. Her widely exhibited video $A$ Loser has its roots in the first Soros-funded exhibitions and has been widely exhibited internationally. 6 The grotesque picture she creates of the artist's status in society serves the dual purpose of describing the daily circumstances of practicing Eastern European artists, while also providing a commentary on the precarious financial position of artists. Manipulating the techniques of serial comedy, she stands in front of the camera and cites her personal data: name, age, weight, address, and salary, each accompanied by background laughter. The Estonian artist is the 'loser' in the new international capitalist context centred on financial success. Kaljo's $A$ Loser follows the dissident tradition of performance art in Estonia in her use of her own body as her basic medium of expression. There is an inherent subjectivity and performativity in this work. She fulfills audience expectations of 'East European-ness' in her presentation of her challenging circumstances, and her detailed revelations are characteristic of the specific context of the Estonian contemporary art world around 1997. Her image carries different meanings in different representational economies: as a location for projected viewer desires, as a consideration of complicated ambivalence and disparate feminist theories, and in the form of psychoanalytic readings rendered visible via her articulation and facial expressions.

Yet perhaps the most relevant aspect of this video are her final words. Kaljo's $\mathrm{CV}$ ends with the statement: "I believe the most important thing about being an artist is freedom." While this is most commonly read by the international art world in terms of its political implications, the statement also reflects what has been articulated as the expected 'East European' condition: the naiveté of the early 1990s, the disillusionment of internationalism, and most of all the aggressive capitalism that became the reality for artists in Estonia and that was linked to the overbearing influence of the Soros foundation. Despite the optimistic mandate of the SCCA, the centres entered the regional cultural environment when the Baltic communities as a whole were experiencing a shocking loss of illusions as documented by Kaljo. The experience of relative isolation of the previous decades had left many artists

6 Born in Tallinn, Kaljo studied classical music at a specialized secondary school and then worked in youth theatre as a stage designer. She studied painting at Tallinn Art University from 1983 to 1990 and continued with her postgraduate education at the Swedish Royal Academy of Arts in 1992. 
and arts professionals with one-dimensional and utopian understandings of Western art and its systems, in which absolute freedom in creative expression and financial support were believed always to coincide peacefully. Furthermore, understanding of the intricacies of the art market was severely limited and most artists failed to fulfill their dreams of instant riches and independent success. As a result, the mental space between idealized expectations and reality was often filled with bitterness, accusations, pretensions, and oftentimes schizophrenic responses. Kaljo's video commentary thus effectively undermines the legitimacy of Soros's policies by employing the foundation's preferred medium in a way that engages another level of complexity in interpretations of the video as well as of the medium itself.

As the international art world and its funding structures demanded a particular performative 'brand' of East European-ness recognizable in its art works (in form, style, and most importantly philosophy), the functional and conceptual reinterpretation of reality Kaljo achieves or the cultural processes that she reinterprets by exhibiting East European-ness both interfere with the audience's value systems and require a rethinking. Where Kaljo centres the 'self' as subject in an overt commentary on and critique of the material circumstances of the Estonian artists in the contemporary art world, Jaan Toomik's Way to Sao Paulo is illustrative of an artist's metaphysical journey to the international art world while employing the deeply historical tradition of landscape in the region. In Estonian, as in most Baltic art, the author or artist's 'self had traditionally been marginalized in art history (with the exception of non-conformist discourses of performance art), with the focus instead being placed on landscape and scene-based work done in oil paintings following the broader tradition of Nordic art history (see Rosenfeld and Dodge 2002). Furthermore, the subversion of the self as demonstrated by Toomik testifies to a conformity with socialism and a retreat into personal life. It is only in the video art of the 1990s that Estonia saw the clear emergence of the artist as both performer and subject that challenged previous art historical and sociopolitical traditions through strategies directed towards examining the personal, the meditative, the 'artistic' self.

Born in Tartu, educated at the Estonian Academy of Art, and based in Tallinn, Jaan Toomik works and exhibits around the world. Toomik claims that his wish of being an artist dates as far back as 1976 when he saw an interview with the acclaimed Estonian artist Aili Vint on television. Following his service in the Soviet army in Afghanistan in the 1980s, Toomik's work consisted mostly of traditional paintings that conveyed mythological tropes, locally and universally recognizable narratives that he further developed in his later performances and post-conceptual works. His videos lack the frenetic vibrations customary to video art and are dependent upon repetitive structures that resonate with concentrated meditations on reality in a vein similar to Kaljo's. 
Toomik's more established video works of the 1990s show him alone and in motion. In Dancing Home (1995) the artist is seen dancing on the rear deck of a passenger ferry during the fifty-mile journey from Helsinki to Tallinn. ${ }^{7}$ His journey across the ideological and geographical frontier of the Cold War era functions as a metaphor for the artist's first tentative steps towards the international art world as a participant in an exhibition at the internationally renowned Kiasma Museum of Contemporary Art in Helsinki. Toomik's breakthrough in the international contemporary art mainstream provides further clarity on the strategic use of the artistic self by Estonian artists in their internationally oriented works. In 1994 Toomik documented his own personal and physical journey from his modest beginnings in Estonia to the international art world at the Sao Paulo biennial, his first major exhibition abroad. His installation Way to Sao Paulo uses documentary footage of a large mirrored cube floating down the rivers of the three cities that led him to the exhibition. The journey of the cube begins on the river Tartu in the town of Toomik's birth. It then proceeds through Prague, the city now often considered to be the geographical centre of Europe. The final segment shows the mirrored cube floating down a river in Sao Paulo, the place of Toomik's arrival in the international art arena. The footage therefore creates a geographical and symbolical path from his childhood to the present.

Because of its physical and metaphorical potential, the use of mirrors was prevalent in the post-conceptualist works produced by artists from the former East in the 1990s. As tokens of narcissism, particularly when reinforced by the medium of video, reflective devices were employed as a strategy to express anything from straightforward interpretations of art as a 'mirror of the world' to complex reflections on how identity is formed and on how word and image interrelate. The curators Peter Weibel and Andrea Buddensieg propose that artists have a "tendency to adopt fictional identities for the purposes of reacting by role-play to every new context in which they become artists. Self-representation is no longer a portrait in the former sense of the meaning, but rather the performance of roles played for a specific audience" (Weibel and Buddensieg 2011). Yet Toomik's physical absence from the reflection of the mirrored cube subverts this notion and instead functions additionally as a commentary on the power dynamics of the gaze in relationships of power. His absence from the image places the onus of interpretation on the viewer, in this case the international art world. By resisting the branding typically associated with commonly accepted, yet false, notions of East European-ness, the mirrored cube's refusal of definition serves as a reminder that identity has been rendered unstable.

7 This waterway was also the site of the Estonian ferry disaster of 28 September 1994 in which 852 people perished. 
In conclusion, as the number of video installations and museum screenings has continued to increase in recent years, video art has become more frequently discussed within the paradigms of globalization theory. Yet for many artists from the former Soviet socialist republics, their work in the biennial industry is only visible to the extent to which it figures within the limits of the art world's representational economies of 'otherness.' As the interest in works from the region declined in the mid-1990s due to the assumption of a socio-political 'normalization,' commentary on the relatively superficial elements of aesthetic globalization or standardization has distracted us from the more profound convergences on the levels of economic, sociological, and institutional standardization of an international art world that has become neither radically democratic nor geographically inclusive. It may appear that biennials and international exhibitions have contributed to the diminishing importance of traditional art centres and have pluralized or regionalized the art world, which in the European context skews eastward, to the advantage of semiperipheral areas. Yet as geographical distances seemingly diminish and the international art community reflects on turning into a 'global village' (McLuhan 1962), demonstrations of local specificity remain of predominant interest to art audiences, art professionals, and the art market. These conditions have put pressure on artists emerging from the post-Soviet Baltics to validate and legitimize their artistic origins through demonstrations of locality while simultaneously participating in global discourses.

For artists, this requires a balancing act between the challenge of succeeding in a differentiated art market and making local aesthetic and/or political issues understandable to a global audience at the risk of conforming to, and being overwhelmed by, international standards. While biennials have mobilized and unpacked globalization as an artistic concept in different ways, they have at the same time universalized particular art definitions, artistic practices, audiences, and conceptions of art. At worst, the risk of unique forms of artistic expression being lost to a universalizing standard carries the echo of homogenization of the socialist era as well as imperialism, although the endangerment of originality and authenticity is a situation to which artists from around the globe are privy. Yet the visibility of minor differences in content distracts us from the real convergence of the power dynamics that guide artistic choice. The danger of these broader economic and institutional convergences and their symptomatic aesthetic uniformization lies in the repercussions of catering to aesthetic preferences of specific audiences. This raises critical questions concerning cultural imperialism and the relevance of a postcolonial lens.

As global art communities have continued to expand since the 1990s, biennials and the artists who participate in them remain geographically and politically situated. Biennials have become platforms for grappling with issues of politics, identity, globalization, and diversity and they are places where artistic self-representation 
from the periphery becomes politicized in order to question the hierarchies of the art world. ${ }^{8}$ Yet the quest for 'local' specificity has paradoxically fallen into the trap of a homogenized international art world aesthetic. Both Kaljo and Toomik have been credited for being catalysts for the rebirth of Estonian contemporary art in the international avant-garde style, but the evidence of their work may perhaps be more interestingly employed in a consideration of an urban mobile art elite that recognizably converged in form, style, and content. As such, the examination of the work of Kaljo, Toomik, and others who communicate and participate in this converged culture of the globalized contemporary art world allows for a deeper insight into our networked contemporary condition.

\section{Works Cited}

Groys, Boris. Art Power. Cambridge, MA: MIT Press, 2013.

Helme, Sirje. "The Soros Center for Contemporary Arts: Estonia in the Extreme Decimal." Nosey Nineties: Problems, Themes and Meanings in Estonian Art on the 1990s. Ed. Sirje Helme and Johannes Saar. Tallinn: Center for Contemporary Arts, Estonia, 2001. 35-51.

---. "Estonian Art from 1987 to the Present." Art of the Baltics: The Struggle for Freedom of Artistic Expression under the Soviets, 1945-1991. Ed. Alla Rosenfeld and Norton T. Dodge. New Brunswick, NJ: Rutgers UP and Jan Voorhees Zimmerli Art Museum, 2002. 157-161.

Jenkins, Henry. Convergence Culture: Where Old and New Media Collide. 2006. New York: New York UP, 2008.

Kaljo, Kai. A Loser. 1997. First exhibited in the group exhibition Funny versus Bizarre at the Contemporary Arts Center in Vilnius, Lithuania, 1997. Video. Available online.

McLuhan, Marshall. The Gutenberg Galaxy: The Making of Typographic Man. Toronto: U of Toronto P, 1962.

Rosenfeld, Alla, and Norton T. Dodge, eds. Art of the Baltics: The Struggle for Freedom of Artistic Expression under the Soviets, 1945-1991. New Brunswick, NJ: Rutgers UP and Jan Voorhees Zimmerli Art Museum, 2002.

Toomik, Jaan. Way to Sao Paulo. 1994. First exhibited at the Sao Paulo Biennale in Sao Paulo, Brazil, 1994. Video installation.

8 Renewed aesthetic and economic regionalism such as the Hanseatic cooperation in organizing local-culture projects may be regarded as opposing forces to the trajectory of globalization in the region. 
---. Dancing Home. 1995. First exhibited at ARS '95. Kiasma Museum of Contemporary Art in Helsinki, Finland, 1995. Video installation.

Weibel, Peter, and Andrea Buddensieg. Curatorial statement for the exhibition The Global Contemporary: Art Worlds After 1989. ZKM Museum of Contemporary Art in Karlsruhe, Germany, 17 September 2011 - 5 February 2012. Curators: Peter Weibel and Andrea Buddensieg. 